\title{
Anti-predator behaviour of Sahamalaza sportive lemurs, Lepilemur sahamalazensis, at diurnal sleeping sites
}

\author{
Melanie Seiler ${ }^{1,2}$, Christoph Schwitzer ${ }^{1}$, Marc Holderied ${ }^{2,3}$ \\ ${ }^{1}$ Bristol Conservation and Science Foundation, clo Bristol Zoo Gardens, Clifton, Bristol, BS8 3HA, UK \\ ${ }^{2}$ School of Biological Sciences, University of Bristol, Woodland Road, Bristol, BS8 IUG, UK \\ ${ }^{3}$ E-mail: marc.holderied@bristol.ac.uk
}

Key words: critically endangered, nocturnal primates, fragmentation, playback experiments, predator-specific strategy

\begin{abstract}
In response to predation pressure by raptors, snakes, and carnivores, primates employ anti-predator behaviours such as avoiding areas of high predation risk, cryptic behaviour and camouflage, vigilance and group formation (including mixedspecies associations), and eavesdropping on other species' alarm calls. After detecting a predator, primates can produce alarm calls, show predator-specific escape strategies or even mob the predator. It remains unclear how solitary nocturnal primates respond to diurnal predation pressure while they sleep or rest. The aim of this study was to investigate the diurnal anti-predator behaviour of the nocturnal and solitary Sahamalaza sportive lemur, Lepilemur sahamalazensis, which regularly rests in exposed locations. We observed the responses of 32 Sahamalaza sportive lemurs to playbacks of territorial calls of an aerial predator (Madagascar harrier hawk), mating calls of a terrestrial predator (fossa), and the contact calls of a medium-sized bird (crested coua) as a control, at different diurnal sleeping sites. Lemurs never showed a flight response after replays of predator or control calls, but regularly froze after harrier hawk calls. Lemurs scanned the sky immediately after playback of harrier hawk calls, and the ground or trees after fossa calls. Lemur vigilance increased significantly after both predator calls. After crested coua calls the animals became significantly less vigilant, suggesting that contact calls of this bird serve as indicators of predator absence. We found no response differences between different types of sleeping sites. Our results show that resting Sahamalaza sportive lemurs recognise predator vocalisations as indicators of increased predation risk, discern vocalizations of different predators, and employ anti-predator behaviours specific for different predator classes. Their behavioural responses while resting or sleeping are comparable to those of active primates, and their response rate of $80 \%$ shows that this solitary and nocturnal primate is constantly aware of its environment.
\end{abstract}

\section{Contents}

Introduction

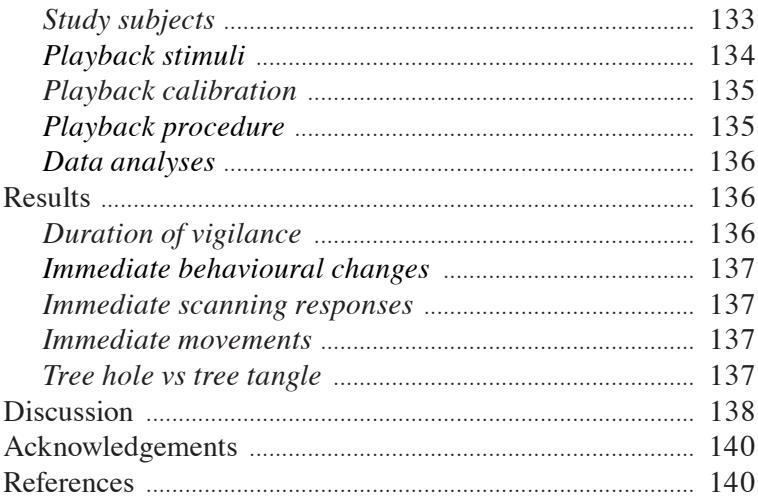

\section{Introduction}

The influence of predation on morphology, behaviour and ecology of animals has long been recognized (Altmann, 1956; Hamilton, 1971; Kruuk, 1972; Curio, 1976; Burtt, 1981). Many reports on mammals and birds illustrate the crucial role of predation pressure on the evolution of anti-predator behaviours (Thompson et al., 1980; Cheney and Wrangham, 1987; Sih, 1987; Lima and Dill, 1990; Seyfarth and Cheney, 1990; Curio, 1993; Zuberbühler, 2000; Caro, 2005; Gursky and Nekaris, 2007; Scheumann et al., 2007; Fichtel, 2012). Raptors, snakes, and carnivores pose a predation risk for most wild primates (Cheney and Seyfarth, 1981; Cheney, 1987; Cowlishaw, 1994; Janson and van Schaik, 1993; Isbell, 1994; Hill and Dunbar, 1998; Treves, 1999; Bearder et al., 2002; Gursky, 2002a, b; Shultz and Noë, 2002). In response to predation pressure, primates use anti-predator behaviours such as crypsis, camouflage, and avoidance of areas of high predator density to reduce detection risk, and individual and group vigilance (even in mixed-species associations) to improve predator 
detection, which can include eavesdropping on other species' alarm calls (Vine, 1973; Seyfarth et al., 1980; van Schaik and van Hooff, 1983; Terborgh and Janson, 1986; Janson, 1992; Cowlishaw, 1994; Wright, 1998; Fallow and Magrath, 2010). After being detected by a predator, primates have been reported to mob the predator, show predator-specific escape strategies and emit alarm calls (Seyfarth et al., 1980; van Schaik and van Hooff, 1983; Sullivan, 1984; Isbell, 1994; Bshary and Noë, 1997; Zuberbühler et al., 1999; Fichtel and Kappeler, 2002; Stanford, 2002; Karpanty and Wright, 2007; Scheumann et al., 2007).

Responses of nocturnal primates to predation pressure have not been studied in as much depth as those of diurnal species, despite the former making up nearly one third of the primate order. Cryptic behaviour and camouflage have been assumed to be the main antipredator strategies of nocturnal primates (Vine, 1973; Terborgh and Janson, 1986; Janson, 1992; Cowlishaw, 1994; Wright, 1998). In the past decade, however, experimental studies revealed that nocturnal primates exhibit predator-specific escape strategies as well as alarm calls, and that they make use of anti-predator strategies such as early detection, warning of approaching predators and mobbing behaviour - anti-predator strategies that also are common in diurnal primates (Fichtel, 2007; Rahlfs and Fichtel, 2010). Indeed, nocturnal primates might not only face high predation pressure while active at night, but also are exposed to predation from diurnal or cathemeral predators while inactive and resting in their shelters during the day (Wright, 1998; Schülke and Ostner, 2001; Karpanty, 2006). In Madagascar, a harrier hawk (Polyboroides radiatus Scopoli, 1786) for example has been observed extracting a nocturnal lemur (Lepilemur ruficaudatus Grandidier, 1867) from its daytime sleeping tree holes by pulling it through cracks using its beak (Schülke and Ostner, 2001). Fossas (Cryptoprocta ferox Bennett, 1833) and boas (e.g. Boa manditra Kluge, 1991), which also hunt during day and night, have been reported to successfully prey on different nocturnal species (Wright, 1998; Goodman, 2003; Karpanty, 2006).

Due to the diversity of their social systems (solitary, dispersed pairs, harems) and their exposed resting locations, the sportive lemurs (Lepilemur spp.) of Madagascar lend themselves to the study of antipredator strategies of nocturnal prosimians (Tattersall, 1982; Harcourt and Thornback, 1990; Groves, 2001; Mittermeier and Nash, 2006). To date, anti-predator behaviour has been studied in one pair-living sportive lemur species, the red-tailed sportive lemur (L.ruficaudatus Fichtel, 2007), which distinguished between different predator types, increased vigilance and usually showed predator-specific flight responses. Solitaryliving species, which rest and forage on their own, cannot profit from group benefits of predator avoidance (Stanford, 2002), either during activity or during resting periods (Radespiel et al., 1998, 2003). Mobbing of predators was also observed in solitary animals, though, and can be successfully used to confuse and discourage
Fig. 1. Habitat map indicating study fragments in the Ankarafa Forest, Sahamalaza Peninsula, northwest Madagascar.
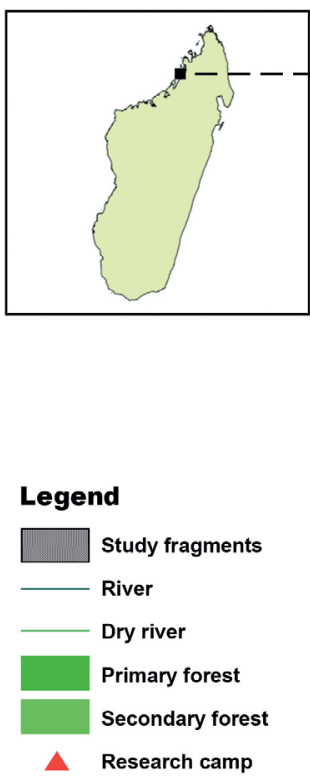
the predator (Zuberbühler et al., 1999; Clark, 2005). Studies on how solitary-living sportive lemurs respond to high predation pressure during the day have as yet not been carried out.

Here, we investigate the diurnal anti-predator behaviour of the Sahamalaza sportive lemur, Lepilemur sahamalazensis (Andriaholinirina et al., 2006), from northwestern Madagascar, using the species as a model for a solitary-living nocturnal prosimian. Since its recognition as a species, the Sahamalaza sportive lemur has been included on the list of the World's Top 25 Most Endangered Primates 2006 - 2008 (Mittermeier et al., 2007) and listed as Critically Endangered by the IUCN (C. Schwitzer, pers. comm.). During daylight hours the Sahamalaza sportive lemur rests in tree holes or in tree tangles. Individuals resting in tree holes usually sit at the entrance rather than inside the hole, possibly to increase sun exposure (Seiler et al., 2013a). Therefore, they are more accessible to predators like the Madagascar harrier hawk, the fossa, and possibly the Madagascar tree boa, as well as poachers, as each of these predators hunt during sportive lemur resting periods. During our own diurnal observations, 5-14\% of resting sportive lemurs behaviours were considered active, usually including a high proportion of vigilance (Seiler et al., 2013a). To investigate anti-predator responses in the Sahamalaza sportive lemur, we conducted playback experiments during daytime hours on individual sportive lemurs resting in the entrance of tree holes and tree tangles in their natural habitat. To elicit anti-predator behaviour, the vocalisations of two potential and abundant predators, the fossa (mating calls) and the harrier hawk (territorial calls), were played to the sportive lemurs. Contact calls of the abundant crested coua (Coua cristata Linnaeus, 1766) were used as non-predator control calls.

Due to the high level of diurnal exposure and their relatively high level of activity during the day, we hypothesized that the Sahamalaza sportive lemur relies on early detection of predators, a strategy that also is used in other sportive lemur species (Fichtel, 2007). Therefore, we predicted them to increase vigilance after playbacks of possible predators, but not after control calls. Regarding predator class specific responses we predicted them to scan the sky after playbacks of aerial predator calls and to scan the ground or surrounding trees after playback of terrestrial predator calls. We predicted that in response to playbacks of predator calls, the lemurs immediately would either drop into the tree hole/canopy or to freeze. No change in behaviour was predicted in response to the contact calls of the crested coua, as the presence of this nonpredatory bird species represents no danger to sportive lemurs. We predicted stronger reactions from animals resting in tree holes because individuals resting in tree tangles are less visible/exposed to predators, and because their diurnal activity level is lower compared to individuals resting in tree holes (Seiler et al., 2013a).

\section{Material and methods}

\section{Study site}

The Ankarafa Forest is situated in the UNESCO Biosphere Reserve and National Park on the Sahamalaza Peninsula and is part of the Region Sofia, NW Madagascar. It extends between $13^{\circ} 52^{\prime} \mathrm{S}$ and $14^{\circ} 27^{\prime} \mathrm{S}$ and $45^{\circ} 38^{\prime} \mathrm{E}$ and $47^{\circ} 46^{\prime} \mathrm{E}$ (WCS/DEC, 2002; Figure 1). The climate is strongly seasonal, with a cool, dry season from May to October and a hot, rainy season from November to April. The Ankarafa Forest lies in a transition zone between the Sambirano region in the North and the western dry deciduous forest region in the South, harbouring semi-humid forests with tree heights of up to $30 \mathrm{~m}$ (Schwitzer et al., 2006). The forests in this area include a mixture of plant species typical of the western dry deciduous forest as well as some typical of the Sambirano domain (Birkinshaw, 2004) and comprise primary and secondary forest fragments.

No large connected areas of intact primary forest are left on the Sahamalaza Peninsula, and the remaining fragments all show some degree of anthropogenic disturbance and/or edge effects (Schwitzer et al., 2007a, b). The forests and forest fragments are separated by grassland with shrubs. The Sahamalaza sportive lemur is found exclusively in this area. Other lemur species in Sahamalaza include the blue-eyed black lemur (Eulemur flavifrons Gray, 1867), the aye-aye (Daubentonia madagascariensis Gmelin, 1788), the western bamboo lemur (Hapalemur occidentalis Rumpler, 1975), the northern giant mouse lemur (Mirza zaza) and the fattailed dwarf lemur (Cheirogaleus medius Geoffroy, 1812). All lemur species living in Sahamalaza are threatened by hunting and deforestation (Schwitzer $e t$ al., 2006).

\section{Study subjects}

Between April and October 2010, a total of 461 playback experiments were conducted on 32 individual sportive lemurs. 26 animals were resting in tree holes, 6 in tree 
tangles. The first week of the field season was used to walk four adjacent forest fragments during the day to find mature sportive lemurs in their sleeping sites, and to identify them individually by their facial masks. We only chose individuals whose sleeping site/ resting position allowed us to clearly see their faces and thus to observe their behaviour in response to the playback experiments. Before we started conducting playback experiments with the animals we did diurnal observations of all individuals for three days each ( 6 am to 6 $\mathrm{pm})$ to reduce the possible effect of our presence on their behaviour. As this Lepilemur species is not very abundant in the forest (between 0.07 and $0.23 \mathrm{ind} / \mathrm{ha}$; Seiler et al., in press) and individuals occasionally change sleeping sites or disappear, we also conducted playback experiments on previously untested mature sportive lemurs that were first found at least one month before the end of the field season. Due to differences in site fidelity we were not able to play all predator or control calls to all individuals, therefore numbers of sportive lemurs tested in the different categories differ $(\mathrm{N}=29$ for harrier hawk; $\mathrm{N}=26$ for fossa; $\mathrm{N}=27$ for crested coua). Sportive lemurs were resting in tree holes located in dead trees of the species Bridelia pervilleana. Tree tangle sleeping sites were located in the species Sorindeia madagascariensis. Sportive lemurs resting in tree holes rested at the entrance of the tree hole at a height of 3.25 (2.5-4.4) metres (median with interquartile range), animals resting in tree tangles rested slightly higher at 5.65 (5.38-5.98) metres. Tree hole trees had a larger diameter at breast height (22.1 centimetres, range 14.7-24.9) than tree tangle trees (13.5 centimetres, 7.5-25.7), while tree tangles trees were higher (10 metres, 7-14) than tree hole trees (8.3 metres, 3.9-11.3) and also had a higher canopy cover $(87 \%, 83-91)$ than tree hole trees 79\%, 71-89 (see Seiler et al., 2013a).

\section{Playback stimuli}

Territorial calls of harrier hawks and contact calls of crested coua were obtained from the online archive of the Macaulay Library (http://macaulaylibrary.org). Mating calls of fossas were recorded at the study site using a directional microphone (K6 power module and ME67 recording head, Sennheiser electronic GmbH \& Co. KG, Wennebostel, Germany) and a PMD-670 digital recorder (Marantz Japan Inc., Sagamihara, Japan). We used mating calls of six different fossas, territorial calls of six different harrier hawks and contact calls of six different crested couas. Though territorial calls as well as mating calls are not associated with the hunting behaviour of predators, we considered these calls as sufficient for our experiments as they inform the sportive lemur about the presence of a potential predator. All recordings used for playback were equipped with 10 seconds fade in and fade out using SASLAB Pro (Avisoft Bioacoustics, Berlin, Germany). Table 1 summarises acoustic parameters of the calls used, and figure 2 shows example spectrograms of each call type (generated in SASLAB Pro; 1024-point

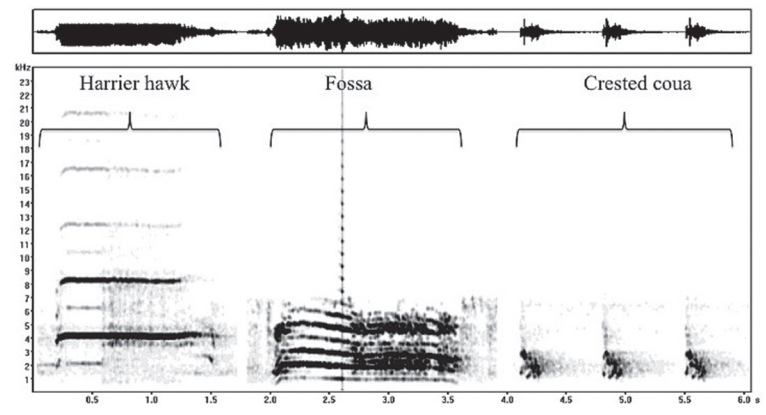

Fig 2. Spectrogram (lower panel) and oscillogram (upper panel) of one of the six copies of calls of harrier hawk, fossa, and crested coua used for playback.

Table 1. Median (interquartile range; Q1 - Q3) stimulus length (start of first call unit to end of last call unit), call duration (duration from call onset to call offset), inter call interval (time gap between call offset and successive call onset), peak frequency of call (measured from power spectrum), and source level (in $\mathrm{dB}$ peSPL re $1 \mathrm{~m}$ ) of harrier hawk, fossa and crested coua recordings used as playback stimuli.

\begin{tabular}{|c|c|c|c|c|c|c|c|}
\hline species & $\mathrm{N}$ & call type & $\begin{array}{l}\text { stimulus } \\
\text { length (s) }\end{array}$ & $\begin{array}{l}\text { call } \\
\text { duration (s) }\end{array}$ & $\begin{array}{l}\text { inter call } \\
\text { interval (s) }\end{array}$ & $\begin{array}{l}\text { mean peak } \\
\text { frequency }(\mathrm{Hz})\end{array}$ & $\begin{array}{l}\text { source level } \\
\text { (dB peSPL) }\end{array}$ \\
\hline Fossa & 6 & mating & $\begin{array}{l}7.7 \\
(5.7-9.3)\end{array}$ & $\begin{array}{l}0.77 \\
(0.4-1.2)\end{array}$ & $\begin{array}{l}0.93 \\
(0.7-2.8)\end{array}$ & $\begin{array}{l}1120 \\
(930-1310)\end{array}$ & $\begin{array}{l}70.6 \\
(70.2-72.4)\end{array}$ \\
\hline Harrier hawk & 6 & territorial & $\begin{array}{l}16.12 \\
(15.3-17.4)\end{array}$ & $\begin{array}{l}1.32 \\
(1.2-1.4)\end{array}$ & $\begin{array}{l}5.62 \\
(5-8.9)\end{array}$ & $\begin{array}{l}3460 \\
(3370-4165)\end{array}$ & $\begin{array}{l}67.8 \\
(65.2-68.9)\end{array}$ \\
\hline Crested coua & 6 & contact & $\begin{array}{l}4.65 \\
(4.5-4.9)\end{array}$ & $\begin{array}{l}0.28 \\
(0.2-0.3)\end{array}$ & $\begin{array}{l}0.69 \\
(0.6-0.8)\end{array}$ & $\begin{array}{l}1960 \\
(1730-2200)\end{array}$ & $\begin{array}{l}70.4 \\
(70.1-74.7)\end{array}$ \\
\hline
\end{tabular}


Hamming window, $48 \mathrm{kHz}$ sampling rate with $50 \%$ window overlap resulting in $47 \mathrm{~Hz}$ frequency resolution, and $10.7 \mathrm{~ms}$ temporal resolution).

\section{Playback calibration}

The calls were played back using an iPod nano, model A1320 (Apple Inc., Cupertino, CA) and wireless loudspeaker (JBL On Stage Micro II; Harman International Industries, Inc., Stamford, CT; Frequency range $80 \mathrm{~Hz}-20 \mathrm{kHz}$ ). The sound pressure level of call playbacks was measured in a semi-anechoic chamber in Bristol using 40BF microphone, 26AB preamplifier and 12AA power module (all G.R.A.S. Sound \& Vibration, Holte, Denmark) calibrated by D1411E acoustic calibrator (Dawe Instruments, Brentford, UK). Mean sound pressure levels (SPL) were 67-71 dB peak-equivalent SPL re $1 \mathrm{~m}$ (see Table 1).

As a field test we played all stimuli in the absence of lemurs in the research camp to check for responses from harrier hawks, fossas or crested couas. We played the harrier hawk territorial calls when buzzards and harrier hawks where in hearing distance, and attracted several individuals of both species. To avoid drawing attention to the resting lemur, we never played back harrier hawk calls if we realized a real harrier hawk or other raptor was close by. We obtained vocal responses from crested couas to their species-specific playbacks, and twice individuals approached us after playbacks. These conspecific responses confirm that our replays in the field were of sufficient quality and adequate sound pressure level. No response from the rare and elusive fossa was ever noted.

\section{Playback procedure}

Playback equipment was either hidden behind a bush or in a tree at a horizontal distance of about five metres from the sportive lemurs sleeping site. The observer was seated at a different position at least five metres away from the playback equipment. The equipment was placed on the ground for the playback of a fossa and on a branch of at least 0.5 metres in height for playbacks of harrier hawk and crested coua. Occurrence, frequency, and duration of responses (see Table 2, Categories I) were documented using focal animal sampling for five minutes each before and after the playback. Where needed, binoculars were used to observe the animals' behaviour. Notepad and timer were used to note down the animals behaviour. Before starting the five minutes pre-playback observation, we waited for the tested individual to settle to the observer's presence. Sportive lemurs that are not habituated to human presence are vigilant and constantly stare at the potential predator, but return to their usual behaviour (Seiler et al., 2013a) after some minutes if the researcher remains calm and does not further approach the animal. During the five minutes observation interval, the exact time (mm:ss) of the onset and offset of each behaviour was noted. After five minutes, a pre-selected call was played back using a remote control, and the five minutes postplayback observation was started. Additionally, immediate behavioural responses (within $5 \mathrm{~s}$ ) to playback were noted (see Table 2, Categories II). The experimental approach was adapted after Fichtel (2007).

The six different versions of harrier hawk calls were played back between 23 and 39 times resulting in a total of 173 playbacks to 29 different individuals (Table 3,

Table 2. Diurnal ethogram of the Sahamalaza sportive lemur as observed during playback experiments. Durations (in seconds) of category I behaviors were determined within the five minute intervals before and after each playback. Category II was used to quantify behavior immediately (within $5 \mathrm{~s}$ ) after each playback.

I-Behavioral categories in the five minutes before and after call playback

rest Animal sits or lies inactively; eyes closed or open, but without attentive scanning

vigilance Animal fixates a specific direction/component or scans the environment; eyes are wide open; some movement possible

autogroomig Animal grooms itself; licking or gnawing its fur

out of sight Animals is out of sight in the tree hole or canopy

II - Behavioral categories immediately (within 5 s) after call playback

scanning up Animal is vigilant and looks up into sky or trees

scanning down Animal is vigilant and looks down to the ground

hide Animal drops into tree hole or climbs into dense canopy; swift

freeze Animal stops any movement but stays vigilant; gaze directed at sky or ground; eyes wide open and not blinking; muscles tense 
Table 3. Overview of numbers of playback-experiments conducted with six different versions of harrier hawk territorial call, fossa mating call and crested coua contact call with sportive lemur resting at two types of sleeping sites (tree hole: TH; tree tangle: TT).

\begin{tabular}{|c|c|c|c|c|c|c|c|c|c|c|c|c|c|c|c|c|c|c|c|}
\hline \multirow[b]{2}{*}{ Call Nr. } & \multicolumn{4}{|c|}{ Harrier hawk } & \multicolumn{5}{|c|}{ Fossa } & \multicolumn{9}{|c|}{ Crested coua } & \multirow[t]{2}{*}{ Tota } \\
\hline & 1 & 2 & 3 & 4 & 5 & 6 & 1 & 2 & 3 & 4 & 5 & 6 & 1 & 2 & 3 & 4 & 5 & 6 & \\
\hline TH $(n=26)$ & 33 & 29 & 25 & 20 & 21 & 23 & 26 & 18 & 19 & 19 & 20 & 16 & 32 & 23 & 22 & 21 & 19 & 15 & 401 \\
\hline $\mathrm{TT}(\mathrm{n}=6)$ & 6 & 3 & 3 & 3 & 4 & 3 & 3 & 2 & 2 & 4 & 2 & 4 & 4 & 4 & 4 & 3 & 3 & 3 & 60 \\
\hline Total & 39 & 32 & 28 & 23 & 25 & 26 & 29 & 20 & 21 & 23 & 22 & 20 & 36 & 27 & 26 & 24 & 22 & 18 & 461 \\
\hline
\end{tabular}

raw data in On-line Supplementary Material Table S1). The six different fossa calls were presented a total of 135 times to 26 individuals. The six different crested coua calls were played back a total of 153 times to 27 study subjects. All calls were presented in a randomised order to individual lemurs avoiding repeats of the same call recordings. We presented only one playback stimuli per individual per day. Depending on the site fidelity of individual sportive lemurs between one and 48 playback experiments were conducted over a period of six month. As fossas were spotted roaming the forests only at certain times of day, we presented their calls between 6:00 and 9:00 am and between 4:30 and 6:00 pm only. The calls of harrier hawks and crested coua were presented between 6:00 am and 6:00 pm.

\section{Data analyses}

To test for overall differences in response to the different playback stimuli, a Friedman test was used with each individuals mean difference in vigilance during the five-minute periods before and after the playback of stimuli. To test for differences in the duration of individual lemurs' vigilance (measured as seconds of vigilant behaviour) before and after the playback of predator and control calls, we performed a Wilcoxon signed rank test $(\mathrm{P} \leq 0.05)$ with each individuals' mean vigilance duration in the five-minute periods before and after the playback of each stimulus type with Holm's Sequential Bonferroni corrections as post-hoc tests.

To test for response differences between sleeping site types (tree holes vs. tree tangles), we calculated the mean difference in vigilance during the five-minute periods before and after the playback of stimuli of each individual and used Mann-Whitney-U tests $(\mathrm{P} \leq 0.05)$ with Holm's Sequential Bonferroni corrections as post-hoc tests.

To test for immediate responses, scanning or movement directions were either rated as appropriate ('scanning up', 'freeze' and/or 'hide' after harrier hawk calls, 'scanning down', 'freeze' and/or 'hide' after fossa calls; no change/reaction after crested coua calls; compare Table 2) or inappropriate (no change / reaction after harrier hawk and fossa calls; 'freeze' or 'hide' after crested coua calls). $\chi^{2}$ tests with Yates-correction on numbers of appropriate and inappropriate behaviours were used to test for differences in reactions of lemurs (random $=50 \%$; $\mathrm{P} \leq 0.05$ ), separately for scanning and movement reactions. $\chi^{2}$ tests also were used to test for behavioural changes between immediately before and immediately after the playbacks, using total numbers of different behaviours of each individual as unit of analysis.

To exclude the possibility that habituation had an influence on our results, we tested for variation in the difference of duration of vigilance before and after playbacks between the first and the last quarter of playback-experiments conducted on each animal, using a Wilcoxon signed rank test $(\mathrm{P} \leq 0.05)$. No change in the reactions towards presentation of predator and control calls was found $(\mathrm{F}=0.005 ; \mathrm{P}=0.943)$.

\section{Results}

\section{Duration of vigilance}

The tested individuals displayed an overall difference in response to the different playback stimuli (Friedmantest: $\left.\chi^{2}=24.970, \mathrm{P}<0.001\right)$. The duration of vigilance increased after playbacks of fossa and harrier hawk calls (Table 4). Although in $82 \%$ of the cases the individuals calmed down during the five minutes after the playback treatment, in $18 \%$ the individuals remained vigilant for more than five minutes. In $47 \%$ the lemurs did not increase vigilance after the control playback treatment with calls of crested couas. In $47 \%$ the individuals' vigilance was found to even decrease (Table 4). The animals never vocalised in response to the calls of potential predators. 
Table 4. Vigilance in seconds (median with interquartile range, Q1-Q3) within five minutes before and after the playback of harrier hawk $(\mathrm{N}=29)$, fossa $(\mathrm{N}=26)$ and crested coua calls $(\mathrm{N}=27)$ (Wilcoxon signed ranks test; $\mathrm{P} \leq 0.05)$

\begin{tabular}{llll}
\hline & Harrier hawk & Fossa & Crested coua \\
\hline vigilance before call (s) & $78(0-162.5)$ & $82.75(23.9-185.9)$ & $111(35.3-268)$ \\
vigilance after call (s) & $256.5(98.5-300)$ & $267.5(161.3-300)$ & $79.5(8.8-160)$ \\
Wilcoxon Signed Ranks Test & $\mathrm{Z}=-3.731 \mathrm{P}<0.001$ & $\mathrm{Z}=-3.749 \mathrm{P}<0.001$ & $\mathrm{Z}=-2.581 \mathrm{P}=0.01$ \\
\hline
\end{tabular}

Table 5. Percentages of behaviour observed immediately before and after presentation of territorial calls of harrier hawk, mating calls of fossa and contact calls of crested couas. $\chi^{2}$ test (rate $50 \%$; $\mathrm{P} \leq 0.05)$.

rest $\% \quad$ vigilance $\% \quad$ autogrooming $\%$

\begin{tabular}{llll}
\hline Harrier hawk & & & \\
\hline before & 73 & 23 & 7 \\
after & 24 & 74 & 2 \\
& $\chi^{2}=43.506$ & $\chi^{2}=46.095$ & $\chi^{2}=2.778$ \\
& $\mathrm{P}<0.05$ & $\mathrm{P}<0.05$ & $\mathrm{P}>0.1$ \\
\hline
\end{tabular}

Fossa

\begin{tabular}{llll}
\hline before & 73 & 22 & 5 \\
after & 24 & 76 & 0 \\
& $\chi^{2}=37.565$ & $\chi^{2}=39.273$ & $\chi^{2}=27.895$ \\
& $\mathrm{P}<0.05$ & $\mathrm{P}<0.05$ & $\mathrm{P}<0.005$ \\
\hline
\end{tabular}

Crested coua

\begin{tabular}{llll}
\hline before & 65 & 28 & 7 \\
after & 65 & 32 & 4 \\
& $\chi^{2}=0.115$ & $\chi^{2}=0.269$ & $\chi^{2}=1.000$ \\
& $\mathrm{P}>0.1$ & $\mathrm{P}>0.1$ & $\mathrm{P}>0.1$ \\
\hline
\end{tabular}

\section{Immediate behavioural changes}

$78 \%$ of the tested sportive lemurs for fossa calls and $81 \%$ for harrier hawk calls immediately became vigilant in response to the playbacks of predator calls, whilst only $13 \%$ of the tested individuals changed behaviour to vigilance after coua calls. The percentage of vigilance increased from $22 \%$ and $23 \%$ immediately before to $76 \%$ and $74 \%$ immediately after the playback of fossa and harrier hawk calls, respectively (Table 5). In contrast, vigilance did not change in response to the presentation of crested coua calls ( $28 \%$ vs $32 \%$ ).

\section{Immediate scanning responses}

In $73 \%$ of harrier hawk calls and in $100 \%$ of fossa calls, individual sportive lemurs showed appropriate scanning behaviour. In immediate response to playbacks of harrier hawk calls, lemurs scanned the sky, but not the ground or trees $\left(\mathrm{df}=22 ; \chi^{2}=70.35, \mathrm{P}<0.001\right.$, Table 6$)$. The lemurs never looked directly at the speaker, but tended to scan the sky above the speaker. After playback of fossa calls, individuals scanned the ground (toward the speakers) or trees significantly more often than the sky $\left(\mathrm{df}=17 ; \chi^{2}=220.85, \mathrm{P}<0.001\right.$,Table 6$)$. In response to crested coua call playbacks the sportive lemurs displayed an immediate change of scanning direction during only $9 \%$ of calls, and in all of those cases the lemurs reacted in response to real crested couas or other birds $\left(\mathrm{df}=21 ; \chi^{2}=197.21, \mathrm{P}<0.001\right.$; Table 6) who entered the area attracted to the calls.

\section{Immediate movements}

With regard to movements, sportive lemurs showed significantly more appropriate behaviour, (freezing in $92 \%$ of the cases) after playbacks of harrier hawk calls $\left(\mathrm{df}=22 ; \chi^{2}=34.47, \mathrm{P}<0.05\right.$, Table 6$)$. In response to the call, individuals rapidly looked up, and then froze in that position. Interestingly, on two occasions they hid in the tree hole after real harrier hawks flew by. After playbacks of fossa calls however the animals showed appropriate and inappropriate responses in similar frequencies $\left(\mathrm{df}=17 ; \chi^{2}=23.75, \mathrm{P}>0.1\right.$, Table 6$)$. In response to crested coua calls individuals showed significantly more appropriate behaviour, though, that meant they did not react except in one case where a real crested coua approached the lemur $\left(\mathrm{df}=21 ; \chi^{2}=284.43\right.$, $\mathrm{P}<0.001$, Table 6).

\section{Tree hole vs tree tangle}

There were no significant differences in vigilance during the five minutes before and after the playbacks between lemurs resting in tree holes $(\mathrm{N}=24$ for harrier hawk calls; $\mathrm{N}=22$ for fossa calls; $\mathrm{N}=24$ for crested coua calls) and those resting in tree tangles $(\mathrm{N}=5$ for harrier hawk calls, $\mathrm{N}=4$ for fossa calls; $\mathrm{N}=3$ for crested coua calls; Mann-Whitney U-test $\mathrm{F}=1503.0 \mathrm{P}=0.442$ for 
Table 6. Appropriate reactions (APP: look up for harrier hawk, look down for fossa, no change for crested coua) and inappropriate reactions (INAPP: look down/no change for harrier hawk, look up/no change for fossa, look up/look down for crested coua) of scanning direction of tested Lepilemurs and APP (freeze/hide in canopy or tree hole for harrier hawk and fossa, no change for crested coua) and INAPP (out of tree hole/canopy or no change for harrier hawk and fossa, freeze/hide in tree hole/canopy for crested coua) of tested Lepilemurs. $\chi^{2}$ test (rate 50\%; $\mathrm{P} \leq 0.05$ ); Degrees of freedom (Df) $=22$ for harrier hawk, 17 for fossa, 21 for crested coua.

\begin{tabular}{|c|c|c|c|c|c|c|c|c|c|}
\hline & \multicolumn{3}{|c|}{ Harrier hawk } & \multicolumn{3}{|c|}{ Fossa } & \multicolumn{3}{|c|}{ Crested coua } \\
\hline & APP & INAPP & & APP & \multicolumn{2}{|l|}{ INAPP } & APP & \multicolumn{2}{|c|}{ INAPP } \\
\hline \multicolumn{10}{|c|}{ scanning direction } \\
\hline$\Sigma$ & 113 & 55 & $\chi^{2}=70.35$ & 121 & 4 & $\chi^{2}=220.8$ & 132 & 145 & $\chi^{2}=197.21$ \\
\hline & & & $\mathrm{P}<0.001$ & & & $\mathrm{P}<0.001$ & & & $\mathrm{P}<0.001$ \\
\hline \multicolumn{10}{|c|}{ movement } \\
\hline$\Sigma$ & 97 & 71 & $\begin{array}{l}\chi^{2}=34.47 \\
\mathrm{P}<0.05\end{array}$ & 67 & 56 & $\begin{array}{l}\chi^{2}=23.75 \\
P>0.1\end{array}$ & 145 & 1 & $\begin{array}{l}\chi^{2}=284.43 \\
P<0.001\end{array}$ \\
\hline
\end{tabular}

harrier hawk calls; $\mathrm{F}=942.5, \mathrm{P}=0.687$ for fossa calls; $\mathrm{F}=1418.5 ; \mathrm{P}=0.916$ for crested coua calls).

\section{Discussion}

We present the first data on the diurnal anti-predator behaviour of a nocturnal, solitary-living sportive lemur species. As individuals of this Critically Endangered species rest relatively exposed during the day, they may have evolved an effective strategy to avoid predation by aerial and terrestrial predators that are hunting during the day. Generally, our results corroborate similar previous research on diurnal as well as nocturnal primates by showing that the studied Sahamalaza sportive lemurs increase vigilance after playbacks of predator calls and show initial responses that are specific for a predator class (Macedonia and Polak, 1989; Macedonia, 1990; Zuberbühler et al., 1999; Fichtel and Kappeler, 2002; Fichtel, 2007; Karpanty and Wright, 2007, Rahlfs and Fichtel, 2010). After replay of fossa and harrier hawk calls vigilance behaviour of tested individuals increased and sometimes even lasted for over five minutes, suggesting that the Sahamalaza sportive lemur uses early acoustic detection of predators. After playbacks of the crested coua contact calls that were used as a control, the animals reduced vigilance, most likely because the presence of these calls indicates that no predator had been spotted by the crested coua. Lemurs scanned the sky after calls of harrier hawks, and scanned the ground or trees after calls of fossas, indicating that they were able to recognize and distinguish between calls of dif- ferent predators and respond adequately to the different hunting strategies of aerial and terrestrial predators. As tested sportive lemurs responded adequately to all three call stimuli throughout the whole testing period and repeated presentation of the playback stimuli, we ruled out bias by habituation to our presence or the replays.

Similar responses to predator calls are known from playback experiments on different primate species: brown-mantled tamarin (Saguinus fuscicollis Spix, 1823) and mustached tamarin (S. mystax (Spix, 1823); Heymann, 1990; Peres, 1993); Diana monkey (Cercopithecus diana (Linnaeus, 1758); Zuberbühler et al., 1997) and Campbell's monkey (C. campbelli (Waterhouse, 1838); Zuberbühler, 2001); in lemurs: the cathemeral red-fronted lemur (Eulemur rufus Audebert, 1799) and eastern lesser bamboo lemur (Hapalemur griseus Link, 1795), the diurnal Milne-Edwards' sifaka (Propithecus edwardsi (Grandidier, 1871); Karpanty and Wright, 2007) and Verreaux's sifaka (P. verreauxi (Grandidier, 1867); Brockman, 2003). Similar to the Sahamalaza sportive lemur, these primates discriminated between aerial and terrestrial predators and became more vigilant after call playbacks. Contrary to our results, in all previous studies the animals showed distinct flight responses to different types of predators. The brown-mantled tamarin and the mustached tamarin (Heymann, 1990; Peres, 1993) for example looked upwards and quickly descended in response to aerial predators, while in response to terrestrial predators, they looked downwards and sometimes approached the predator. Similar to the Sahamalaza sportive lemur, active nocturnal primates were able to distinguish 
between different predator types and increased their vigilance, but additionally they usually showed flight responses (red-tailed sportive lemur: Fichtel, 2007; spectral tarsiers, Tarsius tarsier (Erxleben, 1777); Gursky, 2006; Gursky and Nekaris, 2007). Spectral tarsiers, which are secondarily nocturnal (Martin and Ross, 2005), are reported to freeze and sometimes show mobbing behaviour in response to a raptor model, and to climb upwards and mob carnivore or snake models. They also produce different types of alarm calls in response to aerial or terrestrial predators (Gursky, 2006; Gursky and Nekaris, 2007).

Active red-tailed sportive lemurs that lived in dispersed pairs, remained stationary and scanned the sky in response to harrier hawk calls, and fled or climbed up, scanned the ground and increased their scanning rate in response to fossa calls (Fichtel, 2007). The author suggested that vigilance is an important anti-predator behaviour of sportive lemurs, which is corroborated by our observations on Sahamalaza sportive lemurs. Contrary to our study, Fichtel (2007) conducted playbacks at night while the lemurs were active, which might explain the stronger flight responses of individuals compared to our findings on diurnal resting. Even though it could profit from warning pair-partner and offspring, the red-tailed sportive lemur did not produce alarm calls (Fichtel, 2007), like the solitary Sahamalaza sportive lemur in our study. Other studies on pairliving sportive lemur species report on loud vocalisation during periods of activity (Rasoloharijaona et al., 2006; Méndez-Cárdenas et al., 2008; Méndez-Cárdenas and Zimmermann, 2009), as found in the Sahamalaza sportive lemur (Seiler, 2012), and Rabesandratana et al. (2006) reported that a Milne-Edwards' sportive lemur emitted loud bark sequences when being chased by a fossa. The lemur changed its' vocalisation to louder shrill and chatter calls when the fossa had nearly grabbed it, and other sportive lemurs were attracted by the vocalisations. Similarly, a red-tailed lemur resting in a tree hole that was attacked by a Madagascar harrier hawk emitted loud distress calls (Schülke and Ostner, 2001). In comparison, both other Lepilemur species are more vocal than the Sahamalaza sportive lemur, which might be due to the fact that they live in dispersed pairs, whilst the Sahamalaza sportive lemur is a solitary species (Seiler, 2012). Lemurs might specifically use loud vocalisations when under attack to startle the predator (Scheumann et al., 2007). In the case of the Sahamalaza sportive lemur, we have never observed a predator attack and therefore do not know whether it uses vocalisations in that situation. In gen- eral, it would be counterproductive for a solitary lemur to use alarm calls in response to predator vocalisation, as this might draw the predator's attention. If the predator already detected the lemur, it might be advantageous for the individual to mob the predator, as shown in other solitary animals (Zuberbühler et al., 1999; Clark, 2005).

So far, only individually caged grey mouse lemurs (Microcebus murinus Miller, 1777) have been reported to not show flight responses when presented with predator models of fossas and raptors, but to increase vigilance towards the predator replicas (Rahlfs and Fichtel, 2010). The latter suggested that the observed vigilance behaviour is adapted to the hunting strategy of their predators, as many terrestrial predators, including the fossa, are stalking or sit-and-wait predators, relying on an element of surprise to capture their prey (Schaller, 1968, 1972). Once prey detects a predator, the latter usually is monitored in order not to grant another chance to strike (Schaller, 1967). This might also be the case for the Sahamalaza sportive lemur. A sportive lemur detecting a fossa could calmly keep track of the predator and decide to flee only if it becomes likely to attack. Similar to the reactions of Sahamalaza sportive lemurs after the playbacks of harrier hawk calls, the raptor model in the study of Rahlfs and Fichtel (2010) did elicit freezing behaviour in grey mouse lemurs. That is probably due to the hunting techniques used by birds of prey, which either actively search in flight or perchhunt (Jaksić and Carothers, 1985). As raptors rely heavily on visual or acoustic cues to detect their prey, moving animals are perceived more easily than stationary ones (Rice, 1983). Thus, it should be advantageous for prey to remain immobile and freeze as soon as an avian predator is detected (Fitzgibbon, 1990; Caro et al., 2004).

The Sahamalaza sportive lemurs in this study did not show specific flight behaviour, unlike most diurnal and active nocturnal primates, but seem to use a similar strategy as described for mouse lemurs by Rahlfs and Fichtel (2010). Only twice after harrier hawk call playbacks did an individual flee into its tree hole, but only when a bird incidentally flew close by. In most other cases the animals froze. As individual Sahamalaza sportive lemurs are well camouflaged it might be sufficient to freeze when hearing but not yet seeing a raptor. During diurnal qualitative observations individuals usually dropped down in their tree hole as soon as a large bird, not necessarily a predator, flew by. This hints at a graded response strategy where it is adequate to initially assess from where the predator approaches, to 
look into the respective direction(s), and to decide what to do based on further observations (Kirchhof and Hammerschmidt, 2006). This would be adaptive as it reduces the costs of unnecessary responses to such frequent signals as the territorial calls of harrier hawks that can be heard regularly all day. It should be particularly relevant for this species to control energetic costs, as red-tailed sportive lemurs reportedly have some of the lowest resting metabolic rates of all mammalian folivores, about $50 \%$ below that predicted for their body mass (Schmid and Ganzhorn, 1996).

We furthermore tested for differences in vigilance between Sahamalaza sportive lemurs occupying different sleeping site types (tree holes vs. tree tangles). Our previous study (Seiler et al., 2013a) found a significantly higher diurnal vigilance in lemurs resting in tree holes and we argued that this might be due to the increased risk of being detected by raptors. Individuals in tree holes might be easier to spot for raptors as they rest in the entrance of the holes and because such trees that have poorer canopy cover compared to tree tangle trees (Seiler et al., 2013a). The additional investment in vigilance suggests a compensating probably thermoregulatory benefit from exposed resting at tree hole entrances. Animals usually presented as much body surface as possible to direct sunlight. Furthermore, multiple flight routes are available to animals resting in tree tangles whilst individuals in tree holes could just hide in their tree holes, which often had sizeable cracks. Nonetheless, Sahamalaza sportive lemurs resting in tree holes did not respond more strongly to predator calls than animals resting in tree tangles, suggesting that individuals in both sleeping site types face a similar predation risk once a predator is close by. Even though individuals resting in tree tangles might face a lower risk of being detected by a predator compared to individuals in tree holes, they should keep track of the predator to be able to flee fast enough in case of detection by the predator.

Generally, the high amount of vigilance during the day might suggest that a certain degree of cathemerality is of advantage for this nocturnal lemur species. As we have never seen the animals travelling or feeding during the day it cannot be classified as purely cathemeral, though. Tattersall (1987) defines cathemerality as follows: "The activity of an organism may be regarded as cathemeral when it is distributed approximately evenly throughout the $24 \mathrm{~h}$ of the daily cycle, or when significant amounts of activity, particularly feeding and/ or travelling, occur within both, the light and dark portions of that cycle." Nonetheless, we suggest a high amount of vigilance during the day might not only be of advantage for the Sahamalaza sportive lemur, but also for every other nocturnal animal species that rests in rather open sites and has predators with reversed activity patterns.

In conclusion, our results suggest that resting Sahamalaza sportive lemurs respond to the diurnal predation pressure by relatively energy-saving predator-specific behaviours that include early acoustic detection, crypsis and keeping track of predators. These behaviours have previously been known from active diurnal or nocturnal primate species, but not for resting primates. The finding that even resting nocturnal lemurs show antipredator behaviour that is specific for either terrestrial or aerial predators and increased vigilance, has important implications for their daily time and energy budgets, and might similarly apply to other primate species that have predators with reverse activity patterns.

\section{Acknowledgements}

We would like to thank Madagascar National Parks (MNP), especially the director of Sahamalaza - Iles Radama National Park, M. ISAIA Raymond, for their continuing collaboration. Thank you also to the DGEF and CAFF/CORE for granting us research permits for our work in Sahamalaza, and to Prof. RABARIVOLA Clément for his ongoing help. Jeremy Cusack, Anna Rudzinski and Lucy Todd, along with all Ankarafa field guides, contributed substantially to the data collection. We also thank three anonymous reviewers and the editor for their helpful comments. MS was funded by Bristol Conservation and Science Foundation, Association Européenne pour l'Etude et la Conservation des Lémuriens (AEECL), Conservation International Primate Action Fund, Margot Marsh Biodiversity Foundation, Mohamed bin Zayed Species Conservation Fund, International Primatological Society and Christian-VogelFonds.

\section{References}

Altmann SA. 1956. Avian mobbing behavior and predator recognition. Condor 58: 241-253.

Andriaholinirina N, Fausser JL, Roos C, Zinner D, Thalmann U, Rabarivola C, Ravoarimanana I, Ganzhorn JU, Meier B, Hilgartner R, Walter L, Zaramody A, Langer C, Hahn T, Zimmermann E, Radespiel U, Craul M, Tomiuk J, Tattersall I, Rumpler Y. 2006. Molecular phylogeny and taxonomic revision of the sportive lemurs (Lepilemur, Primates). BMC Evolutionary Biology 6: 17.

Bearder SK, Nekaris KAI, Buzzell CA. 2002. Dangers in the night: are some nocturnal primates afraid of the dark? Pp 21-40 in: Miller L, ed., Eat or Be Eaten: Predator Sensitive Foraging Among Primates. Cambridge: Cambridge University Press. 
Birkinshaw CR. 2004. Priority Areas for Plant Conservation. Ravintsara 2: 14-15.

Brockman DK. 2003. Polyboroides radiatus predation attempts on Propithecus verreauxi Folia Primatologica 74: 71-74.

Bshary R, Noë R. 1997. Red colobus and Diana monkeys provide mutual protection against predators. Animal Behaviour 54: 1461-1474.

Burtt EH. 1981. The adaptiveness of animal colors. Bioscience 31: 721-729.

Caro TM. 2005. Antipredator defenses in birds and mammals. Chicago: University of Chicago Press.

Caro TM, Graham CM, Stoner CJ, Vargas JK. 2004. Adaptive significance of anti-predator behaviour in artiodactyls. Animal Behaviour 67: 205-228.

Cheney DL. 1987. Interactions and relationships between groups. Pp. 267-281 in: Smuts BB, Cheney DL, Seyfarth RM, Wrangham RW, Struhsaker TT, eds, Primate societies. Chicago: University of Chicago Press.

Cheney DL, Seyfarth RM. 1981. Selective forces affecting the predator alarm calls of vervet monkeys. Behaviour 76: 25-61.

Cheney DL, Wrangham RW. 1987. Predation. Pp 227-239 in: Smits BB, Cheney DL, Wrangham RW, Struhsaker TT, eds, Primate Societies. Chicago: University of Chicago Press.

Clark RW. 2005. Pursuit-deterrent communication between prey animals and timber rattlesnakes (Crotalus horridus); the response of snakes to harassment displays. Behavioral Ecology and Sociobiology 59: 258-261.

Cowlishaw G. 1994. Vulnerabilityto predation in baboon populations. Behaviour 131: 293-304.

Curio E. 1976. The ethology of predation. New York: Springer Verlag.

Curio E. 1993. Proximate and developmental aspects of antipredator behavior. Advanced study of behavior 22: 135-238.

Erxleben JCP. 1777. Systema regni animalis. Classis I.

Fallow PM, Magrath RD. 2010. Eavesdropping on other species: mutual interspecific understanding of urgency information in avian alarm calls. Animal Behavior 79: 411-417.

Fichtel C. 2007. Avoiding predators at night: antipredator strategies in red-tailed sportive lemurs (Lepilemur ruficaudatus). American Journal of Primatology 69: 611-624.

Fichtel C. 2012. Predation. Pp. 169-194 in: Mitani JC, Call J, Kappeler P, Palombit R, Silk J, eds, The evolution of primate societies. Chicago: Chicago University Press.

Fichtel C, Kappeler PM. 2002. Anti-predator behavior of groupliving Malagasy primates: mixed evidence for a referential alarm call system. Behavioral Ecology and Sociobiology 51: 262-275.

Fitzgibbon CD. 1990. Anti-predator strategies of immature Thomson's gazelles: hiding and the prone response. Animal Behaviour 40: 846-855.

Gmelin JF. 1788. Revision of "Systema naturae per regna tria naturae, secondum classes, ordines, genera, species, cum characteribus, differentiis synonymis, locis'. Linneaus C, Beir GE, eds. Lipsiae, Germany 1: 1-232.

Goodman S. 2003. Predation on lemurs. Pp. 1221-1228 in: Goodman SM, Benstead JP, eds, The natural history of Madagascar. Chicago: Chicago University Press.

Groves C. 2001. Why taxonomic stability is a bad idea, or why are there so few species of primates (or are there?). Evolutionary Anthropology 10: 192-198.
Gursky S. 2002a. The behavioral ecology of the spectral tarsier, Tarsius spectrum. Evolutionary Anthropology 11: 226-234.

Gursky S. 2002b. Predation on a wild spectral tarsier (Tarsius spectrum) by a snake. Folia Primatologica 73: 60-62.

Gursky S. 2006. Function of snake mobbing in spectral tarsiers. American Journal of Physical Anthropology 129: 601-608.

Gursky S, Nekaris KAI. 2007. Primate Anti-Predator Strategies (Developments in primatology: progress and prospects ). New York. Springer, U.S.

Grandidier, A. Description de quatre espèces nouvelles de Lepidopteres decouvertes sur la cote sud-oust de Madagascar. Revue et Magasin de Zoologie Pure et Appliquee 19: 272-275.

Hamilton WD. 1971. Geometry for the selfish herd. Journal of Theoretical Biology 31: 295-311.

Harcourt C, Thornback J. 1990. Lemurs of Madagascar and the Comoros. The IUCN Red Data Book. IUCN, Gland, Switzerland, and Cambridge, U.K.

Heymann EW. 1990. Reactions of wild tamarins, Saguinus mystax and Saguinus fuscicollis to avian predators. International Journal of Primatology 11: 327-337.

Hill RA, Dunbar RIM. 1998. An evaluation of the roles of predation rate and predation risk as selective pressures on primate grouping behaviour. Behaviour 135: 411-430.

Isbell LA. 1994. Predation on primates: Ecological patterns and evolutionary consequences. Evolutionary Anthropology 3: 61-71.

Jaksić FM, Carothers JH. 1985. Ecological, morphological, and bioenergetic correlates of hunting modes in hawks and owls. Ornis Scandinavica 16: 165-172.

Janson CH 1992. Evolutionary ecology of primate social structure. Pp. 95-130 in: Smith EA, ed., Evolutionary ecology and human behavior. New York: Walter de Gruyter, Inc.

Janson CH, van Schaik C. 1993. Ecological risk aversion in juvenile primates: Slow and steady wins the race. Pp. 57-74 in: Pereira ME, Fairbanks LA, eds, Juvenile primates life history, development and behavior. Oxford: Oxford University Press.

Karpanty S. 2006. Direct and indirect impacts of raptor predation on lemurs in southeastern Madagascar. International Journal of Primatology 27: 239-261.

Karpanty S, Wright PC. 2007. Predation on lemurs in the rainforest of Madagascar by multiple predator species: observations and experiments. Pp. 75-97 in: Gursky S, Nekaris KAI, eds, Primate Anti-Predator Strategies. New York: Springer Press.

Kirchhof J, Hammerschmidt K. 2006. Functionally referential alarm calls in Tamarins (Saguinus fuscicollis and Saguinus mystax) - evidence from playback experiments. Ecology 112: 346-354.

Kluge, AG. 1991. Boine snake phylogeny and research cycles. Miscellaneous Publications, University of Michigan Museum of Zoology 178: 1-58.

Kruuk H. 1972. The spotted hyena: A study of predation and social behavior. Chicago: University of Chicago Press.

Lima SL, Dill LM. 1990. Behavioural decisions made under the risk of predation: a review and prospectus. Canadian Journal of Zoology 68: 619-640.

Linnaeus C. 1766. Systema naturae per regna tria naturae, secundum classes, ordines, genera, species, cum characteribus, differentiis, synonymis, locis. Tomus I. Editio duodecima, reformata. Holmiae. (Laurentii Salvii): 1-532. 
Macedonia JM. 1990. What is communicated in the antipredator calls of lemurs: evidence from playback experiments with Ringtailed and Ruffed Lemurs. Ethology 86: 177-190.

Macedonia JM, Polak JF. 1989. Visual assessment of avian threat in semi-captive ringtailed lemurs (Lemur catta). Behaviour 111: 291-304.

Martin RD, Ross CF. 2005. The evolutionary and ecological context of primate vision. Pp. 1-36 in: Kremers J, ed., The Primate Visual System: A Comparative Approach. Hoboken: John Wiley \& Sons, Ltd.

Méndez-Cárdenas M, Randrianambinina B, Rabesandratana A, Rasoloharijaona S, Zimmermann E. 2008. Geographic variation in loud calls of sportive lemurs (Lepilemur ssp.) and their implications for conservation. American Journal of Primatology 70: 828-838.

Méndez-Cárdenas M, Zimmermann E. 2009. Duetting-a mechanism to strengthen pair bonds in a dispersed pair-living primate (Lepilemur edwardsi)? American Journal of Physical Anthropology 139: 523-532.

Mittermeier RA, Nash SD. 2006. Lemurs of Madagascar (2nd ed., Conservation International tropical field guide series). Washington, DC: Conservation International.

Mittermeier RA, Ratsimbazafy J, Rylands AB. 2007. Primates in Peril: The World's 25 Most Endangered Primates 2006 2008. Primate Conservation 22: 1-40.

Peres CA. 1993. Anti-predation benefits in a mixed-species group of amazonian tamarins. Folia Primatologica 61: 61-76.

Rabesandratana AZ. 2006. Variation Microgeographiques et bioacoustiques de Lepilemur edwardsi (Geoffroy, 1850) dans le Parc National Ankarafantsika (region nord-ouest de Madagascar) (Doctoral dissertation). Université d'Antananarivo, Antananarivo.

Radespiel U, Cepok S, Zietemann V, Zimmermann E. 1998. Sex-specific usage patterns of sleeping sites in grey mouse lemurs (Microcebus murinus) in northwestern Madagascar. American Journal of Primatology 46: 77-84.

Radespiel U, Ehresmann P, Zimmermann E. 2003. Speciesspecific usage of sleeping sites in two sympatric mouse lemur species (Microcebus murinus and M.ravelobensis) in northwestern Madagascar. American Journal of Primatology 59: 139-151.

Rahlfs M, Fichtel C. 2010. Anti-predator behaviour in a nocturnal primate, the grey mouse lemur (Microcebus murinus). Ethology 115: 429-439.

Rasoloharijaona S, Randrianambinina B, Braune P,Zimmermann E. 2006. Loud calling, spacing, and cohesiveness in a nocturnal primate, the Milne Edwards' sportive lemur (Lepilemur edwardsi). American Journal of Physical Anthropology 129: 591-600.

Rice WR. 1983. Sensory modality: an example of its effect on optimal foraging behavior. Ecology 64: 403-406.

Rumpler Y. 1975. The Significance of Chromosomal Studies in the Systematics of the Malagasy Lemurs. Pp. 25-40 in: Tattersall I, Sussman RW, eds. Lemur Biology. New York: Springer Verlag.

Schaik CP van, van Hooff J. 1983. On the ultimate causes of primate social systems. Behaviour 85: 89-117.

Schaller GB. 1967. The deer and the tiger: a study of wildlife in India. Chicago: University of Chicago Press.

Schaller GB. 1968. Hunting behavior of the cheetah in the Serengeti National Park, Tanzania African Journal of Ecology 6: $95-100$.
Schaller GB. 1972. The Serengeti lion: a study of predator-prey relations (Wildlife behavior and ecology). Chicago, London: University of Chicago Press.

Scheumann M, Rabesandratana A,Zimmermann E. 2007. Predation, communication and cognition in lemurs. Pp. 100-126 in: Gursky S, Nekaris KAI, eds, Primate anti-predators strategies. New York: Springer-Verlag.

Schmid J, Ganzhorn JU.1996. Resting metabolic rates of Lepilemur ruficaudatus. American Journal of Primatology 38: 169-174.

Schülke O, Ostner J. 2001. Predation on Lepilemur by a harrier hawk and implications for sleeping site quality. Lemur News 6: 5 .

Schwitzer C, Schwitzer N, Randriatahina GH, Rabarivola C, Kaumanns W. 2006. "Programme Sahamalaza": New perspectives for the in situ and ex situ study and conservation of the blue-eyed black lemur (Eulemur macaco flavifrons) in a fragmented habitat. Pp. 135-149 in: Schwitzer C, Brandt S, Ramilijaona O, Rakotomalala, Razanahoera M, Ackermand D, et al.,eds, Proceedings of the German-Malagasy Research Cooperation in Life and Earth Sciences. Berlin: Concept Verlag.

Schwitzer N, Kaumanns W, Seitz PC, Schwitzer C. 2007a. Cathemeral activity patterns of the blue-eyed black lemur Eulemur macaco flavifrons in intact and degraded forest fragments. Endangered Species Research 3: 293-247.

Schwitzer N, Randriatahina GH, Kaumanns W, Hoffmeister D, Schwitzer C. 2007b. Habitat utilization of blue-eyed black lemurs, Eulemur macaco flavifrons (Gray, 1867), in primary and altered forest fragments. Primate Conservation 22: 79-87.

Scopoli GS. 1986. Scopoli's Ornithological papers from his Deliciae florae et faunae insubricae (Ticini: 1786-1788).

Seiler M. 2012. The impact of habitat degradation and fragmentation on ecology and behaviour of the Sahamalaza sportive lemur, Lepilemur sahamalazensis, in northwest-Madagascar. Doctoral thesis, University of Bristol, Bristol.

Seiler M, Holderied M, Schwitzer C. 2013a. Effects of habitat degradation on sleeping site choice and use in the Sahamalaza sportive lemur, Lepilemur sahamalazensis. International Journal of Primatology 34: 260-280.

Seiler M, Holderied M, Schwitzer C. in press. Vegetation structure of forest fragments in the southern Sambirano domain, northwest Madagascar. Lemur News 17.

Seyfarth RM, Cheney DL. 1990. The assessment by vervet monkeys of their own and another species' alarm calls. Animal Behaviour 40: 754-764.

Seyfarth RM, Cheney DL, Marler P. 1980. Monkey responses to three different alarm calls: Evidence for predator classification and semantic communication. Science 210: 801-803.

Shultz S, Noë R. 2002. The consequences of crowned eagle central-place foraging on predation risk in monkeys. Proceedings of the Royal Society London B 269: 1797-1802.

Sih A. 1987. Predator and prey lifestyles: An evolutionary and ecological overview.Pp. 203-224 in: Kerfoot WC, Sih A, eds, Predation: Direct and indirect impacts on aquatic communities. Hanover, NH: University Press of New England.

Stanford CB. 2002. Avoiding predators: expectations and evidence in primate antipredator behavior. International Journal of Primatology 23: 741-757.

Sullivan K. 1984. Information exploitation by downy woodpeckers in mixed-species flocks. Behaviour 91: 294-311. 
Tattersall I. 1987. Cathemeral Activity in Primates: A Definition. Folia primatologica 49: 200-202.

Tattersall I. 1982. The primates of Madagascar. New York: Columbia University Press.

Terborgh J, Janson CH. 1986. The socioecology of primate groups. Annual Review of Ecology, Evolution, and Systematics 17: 111-136.

Thompson SD, MacMillen RE, Burke EM, Taylore CR. 1980. The energetic cost of bipedal hopping in small mammals. Nature 287: 223-224.

Treves A. 1999. Within-group vigilance in red colobus and redtail monkeys. American Journal of Primatology 48: 113126.

Vine I. 1973. Detection of prey flocks by predators. Journal of Theoretical Biology 40: 207-210.

Waterhouse RW. Catalogue of the mammalia preserved in the Museum of the Zoological Society of London. 1838-1839.

Wright P. 1998. Impact of predation risk on the behaviour of
Propithecus diadema edwardsi in the rainforest of Madagascar. Behaviour 135: 483-512.

Zuberbühler K. 2000. Causal cognition in a non-human primate: field playback experiments with Diana monkeys. Cognition 76: 195-207.

Zuberbühler K. 2001. Predator-specific alarm calls in Campbell's guenons. Behavioral Ecology and Sociobiology 50: 414-422.

Zuberbühler K., Jenny D, Bshary R. 1999. The predator deterrence function of primate alarm calls. Ethology 105: 477-490.

Zuberbühler K, Noë R, Seyfarth RM. 1997. Diana monkey longdistance calls: messages for conspecifics and predators. Animal Behaviour 53: 589-604.

Received: 29 April 2013

Revised and accepted: 16 August 2013

Published online: 1 October 2013

Editor: V. Nijman

\section{On-line Supplementary Information (SI)}

S1. Numbers of playback-experiments conducted with six different versions of harrier hawk territorial call, fossa mating call and crested coua contact call with sportive lemur resting at two types of sleeping sites (tree hole: TH; tree tangle: TT). 


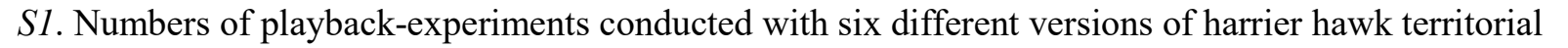

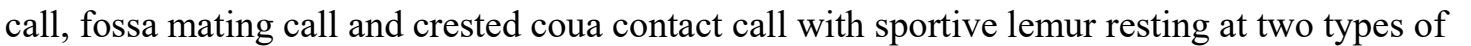

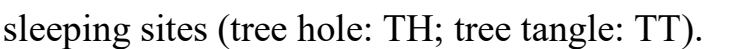

\begin{tabular}{|c|c|c|c|c|c|c|c|c|c|c|c|c|c|c|c|c|c|c|c|}
\hline$\square \square \|$ & $\square[$ & Ш & 11 & & & & $\square \square \|$ & $\| \square$ & & & & & $\square \square$ & \|\|\|\| & \|\|$\|$ & & & & $\square \square$ \\
\hline$\square$ & 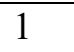 & $\square$ & $\square$ & $\square$ & $\square$ & $\square$ & $\square$ & $\square$ & $\square$ & $\square$ & $\square$ & $\square$ & $\square$ & $\square$ & 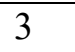 & $\square$ & $\square$ & $\square$ & $\square$ \\
\hline पामि & $\square$ & $\square$ & $\square$ & $\square$ & $\square$ & $\square$ & $\square$ & $\square$ & $\square$ & $\square$ & $\square$ & $\square$ & $\square$ & $\square$ & $\square$ & $\square$ & $\square$ & $\square$ & $\square$ \\
\hline 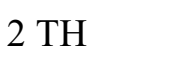 & $\square$ & $\square$ & $\square$ & $\square$ & $\square$ & $\square$ & $\square$ & $\square$ & $\square$ & $\square$ & $\square$ & $\square$ & $\square$ & $\square$ & $\square$ & $\square$ & $\square$ & $\square$ & $\square$ \\
\hline$\square \ln \square$ & $\square$ & $\square$ & $\square$ & $\square$ & $\square$ & $\square$ & $\square$ & $\square$ & $\square$ & $\square$ & $\square$ & $\square$ & $\square$ & $\square$ & $\square$ & $\square$ & $\square$ & $\square$ & $\square \square$ \\
\hline 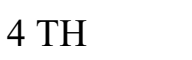 & $\square$ & $\square$ & $\square$ & $\square$ & $\square$ & $\square$ & $\square$ & $\square$ & $\square$ & $\square$ & $\square$ & $\square$ & $\square$ & $\square$ & $\square$ & $\square$ & $\square$ & $\square$ & 1 \\
\hline$\square \square \square \square$ & $\square$ & $\square$ & $\square$ & $\square$ & $\square$ & $\square$ & $\square$ & $\square$ & $\square$ & $\square$ & $\square$ & $\square$ & $\square$ & $\square$ & $\square$ & $\square$ & $\square$ & $\square$ & $\Pi \square$ \\
\hline 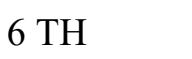 & $\square$ & $\square$ & $\square$ & $\square$ & $\square$ & $\square$ & $\square$ & $\square$ & $\square$ & $\square$ & $\square$ & $\square$ & $\square$ & $\square$ & $\square$ & $\square$ & $\square$ & $\square$ & पा \\
\hline 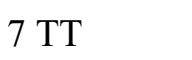 & $\square$ & $\square$ & $\square$ & $\square$ & $\square$ & $\square$ & $\square$ & $\square$ & $\square$ & $\square$ & $\square$ & $\square$ & $\square$ & $\square$ & $\square$ & $\square$ & $\square$ & $\square$ & \\
\hline$\square \square \square$ & $\square$ & $\square$ & $\square$ & $\square$ & $\square$ & $\square$ & $\square$ & $\square$ & $\square$ & $\square$ & $\square$ & $\square$ & $\square$ & $\square$ & $\square$ & $\square$ & $\square$ & $\square$ & $\square$ \\
\hline$\square \square \square \square$ & $\square$ & $\square$ & $\square$ & $\square$ & $\square$ & $\square$ & $\square$ & $\square$ & $\square$ & $\square$ & $\square$ & $\square$ & $\square$ & $\square$ & $\square$ & $\square$ & $\square$ & $\square$ & 111 \\
\hline पामाप्र & $\square$ & $\square$ & $\square$ & $\square$ & $\square$ & $\square$ & $\square$ & $\square$ & $\square$ & $\square$ & $\square$ & $\square$ & $\square$ & $\square$ & $\square$ & $\square$ & $\square$ & $\square$ & $\square \square$ \\
\hline 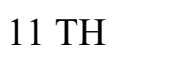 & $\square$ & $\square$ & $\square$ & $\square$ & $\square$ & $\square$ & $\square$ & $\square$ & $\square$ & $\square$ & $\square$ & $\square$ & $\square$ & $\square$ & $\square$ & $\square$ & $\square$ & $\square$ & \\
\hline पाणम & $\square$ & $\square$ & $\square$ & $\square$ & $\square$ & $\square$ & $\square$ & $\square$ & $\square$ & $\square$ & $\square$ & $\square$ & $\square$ & $\square$ & $\square$ & $\square$ & $\square$ & $\square$ & $\square \square$ \\
\hline पाणिए & $\square$ & $\square$ & $\square$ & $\square$ & $\square$ & $\square$ & $\square$ & $\square$ & $\square$ & $\square$ & $\square$ & $\square$ & $\square$ & $\square$ & $\square$ & $\square$ & $\square$ & $\square$ & $\square$ \\
\hline पामाप्र & $\square$ & $\square$ & $\square$ & $\square$ & $\square$ & $\square$ & $\square$ & $\square$ & $\square$ & $\square$ & $\square$ & $\square$ & $\square$ & $\square$ & $\square$ & $\square$ & $\square$ & $\square$ & $\square$ \\
\hline 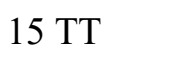 & $\square$ & $\square$ & $\square$ & $\square$ & $\square$ & $\square$ & $\square$ & $\square$ & $\square$ & $\square$ & $\square$ & $\square$ & $\square$ & $\square$ & $\square$ & $\square$ & $\square$ & $\square$ & 11 \\
\hline पाणम & $\square$ & $\square$ & $\square$ & $\square$ & $\square$ & $\square$ & $\square$ & $\square$ & $\square$ & $\square$ & $\square$ & $\square$ & $\square$ & $\square$ & $\square$ & $\square$ & $\square$ & $\square$ & $\square$ \\
\hline पामाप्र & $\square$ & $\square$ & $\square$ & $\square$ & $\square$ & $\square$ & $\square$ & $\square$ & $\square$ & $\square$ & $\square$ & $\square$ & $\square$ & $\square$ & $\square$ & $\square$ & $\square$ & $\square$ & $\square$ \\
\hline पाणी & $\square$ & $\square$ & $\square$ & $\square$ & $\square$ & $\square$ & $\square$ & $\square$ & $\square$ & $\square$ & $\square$ & $\square$ & $\square$ & $\square$ & $\square$ & $\square$ & $\square$ & $\square$ & $\square$ \\
\hline पाणम & $\square$ & $\square$ & $\square$ & $\square$ & $\square$ & $\square$ & $\square$ & $\square$ & $\square$ & $\square$ & $\square$ & $\square$ & $\square$ & $\square$ & $\square$ & $\square$ & $\square$ & $\square$ & $D_{0}$ \\
\hline पाणम & $\square$ & $\square$ & $\square$ & $\square$ & $\square$ & $\square$ & $\square$ & $\square$ & $\square$ & $\square$ & $\square$ & $\square$ & $\square$ & $\square$ & $\square$ & $\square$ & $\square$ & $\square$ & $\square$ \\
\hline पालम & $\square$ & $\square$ & $\square$ & $\square$ & $\square$ & $\square$ & $\square$ & $\square$ & $\square$ & $\square$ & $\square$ & $\square$ & $\square$ & $\square$ & $\square$ & $\square$ & $\square$ & $\square$ & $\Pi$ \\
\hline पालिए & $\square$ & $\square$ & $\square$ & $\square$ & $\square$ & $\square$ & $\square$ & $\square$ & $\square$ & $\square$ & $\square$ & $\square$ & $\square$ & $\square$ & $\square$ & $\square$ & $\square$ & $\square$ & $\square$ \\
\hline पाणम & $\square$ & $\square$ & $\square$ & $\square$ & $\square$ & $\square$ & $\square$ & $\square$ & $\square$ & $\square$ & $\square$ & $\square$ & $\square$ & $\square$ & $\square$ & $\square$ & $\square$ & $\square$ & 11 \\
\hline पाणम & $\square$ & $\square$ & $\square$ & $\square$ & $\square$ & $\square$ & $\square$ & $\square$ & $\square$ & $\square$ & $\square$ & $\square$ & $\square$ & $\square$ & $\square$ & $\square$ & $\square$ & $\square$ & $\square$ \\
\hline पाणम & $\square$ & $\square$ & $\square$ & $\square$ & $\square$ & $\square$ & $\square$ & $\square$ & $\square$ & $\square$ & $\square$ & $\square$ & $\square$ & $\square$ & $\square$ & $\square$ & $\square$ & $\square$ & $\square$ \\
\hline पालिए & $\square$ & $\square$ & $\square$ & $\square$ & $\square$ & $\square$ & $\square$ & $\square$ & $\square$ & $\square$ & $\square$ & $\square$ & $\square$ & $\square$ & $\square$ & $\square$ & $\square$ & $\square$ & $\square$ \\
\hline पाणम & $\square$ & $\square$ & $\square$ & $\square$ & $\square$ & $\square$ & $\square$ & $\square$ & $\square$ & $\square$ & $\square$ & $\square$ & $\square$ & $\square$ & $\square$ & $\square$ & $\square$ & $\square$ & $\square$ \\
\hline पाणमण & $\square$ & $\square$ & $\square$ & $\square$ & $\square$ & $\square$ & $\square$ & $\square$ & $\square$ & $\square$ & $\square$ & $\square$ & $\square$ & $\square$ & $\square$ & $\square$ & $\square$ & $\square$ & $\square$ \\
\hline 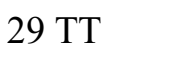 & $\square$ & $\square$ & $\square$ & $\square$ & $\square$ & $\square$ & $\square$ & $\square$ & $\square$ & $\square$ & $\square$ & $\square$ & $\square$ & $\square$ & $\square$ & $\square$ & $\square$ & $\square$ & $\square$ \\
\hline$\square \mid \vec{\square} \square$ & $\square$ & $\square$ & $\square$ & $\square$ & $\square$ & $\square$ & $\square$ & $\square$ & $\square$ & $\square$ & $\square$ & $\square$ & $\square$ & $\square$ & $\square$ & $\square$ & $\square$ & $\square$ & $\square$ \\
\hline 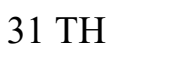 & $\square$ & $\square$ & $\square$ & $\square$ & $\square$ & $\square$ & $\square$ & $\square$ & $\square$ & $\square$ & $\square$ & $\square$ & $\square$ & $\square$ & $\square$ & $\square$ & $\square$ & $\square$ & $\square$ \\
\hline 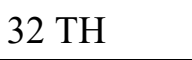 & $\square$ & $\square$ & $\square$ & $\square$ & $\square$ & $\square$ & $\square$ & $\square$ & $\square$ & $\square$ & $\square$ & $\square$ & $\square$ & $\square$ & $\square$ & $\square$ & $\square$ & $\square$ & $\square$ \\
\hline 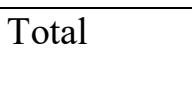 & $\square$ & $\square$ & $\square$ & & $\square$ & & $\square$ & $\square$ & & $\square$ & & $\square$ & & $T$ & $\square$ & ए & 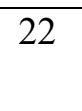 & $\square$ & I \\
\hline
\end{tabular}

